\title{
Teaching chemistry through contemporary research versus using a historical approach
}

\author{
${ }^{1}$ Weizmann Institute of Sience, Department of Science Teaching, Herzl 1 Rehovot, Israel, E-mail: Ron.blonder@weizmann.ac.il. \\ https://orcid.org/0000-0003-4796-4678. \\ ${ }^{2}$ Department of Science Teaching, Weizmann Institute of Science, Rehovot, Israel, E-mail: rachel.mamlok@weizmann.ac.il
}

\begin{abstract}
:
Two different approaches for chemistry education are presented in this paper: teaching and learning chemistry through contemporary research and using a historical approach. Essential dimensions in science education are used to study the differences between the two approaches. This includes the rationale of each approach, the scientific content, as well as students' and teachers' perspectives. At first glance, the two approaches look different and even contradict each other. However, a deeper investigation shows that there are common themes that connect the two approaches. Chemistry education is used to represent the historical approach and Nanoscale Science and Teachnology (NST) in chemistry education is used as the context for learning science through a contemporary research approach. The paper can be used by chemistry teachers as a preliminary guide for consideration of adapting one of these approaches in their class.
\end{abstract}

Keywords: chemistry education, contemporary research, history of science, in-service teachers, nanotechnology DOI: 10.1515/cti-2018-0011

\section{Introduction}

Different approaches for teaching chemistry can be identified in the literature. Two contradictory approaches will be compared in this paper. We would like to present a broad overview of the two approaches, and to introduce chemistry teachers with the rationale of each of them, in order to be able to integrate them while teaching chemistry. The first approach refers to using the historical development of scientific understanding for teaching chemistry and will be referred in the paper as the "Historical Approach", whereas in the second approach, contemporary research serves as the basis for teaching chemistry and will be referred in the paper as the "Contemporary Research Approach". Different criteria are used for the comparison - criteria that are related to different aspects of learning and teaching chemistry. The advantages of each approach and the challenges that teachers and students face are discussed. First, each approach is described, and then specific issues are discussed such as what to teach, and how to teach while referring to the historical aspects or to contemporary research.

\section{What are these two approaches for teaching chemistry?}

\section{Historical approach}

The historical approach deals with topics regarding the role that science has played in the development of various cultures as an ongoing, changing enterprise, such as: (1) the development of scientific models in relation to economic and social aspects in different eras, (2) different aspects of scientific inquiry related to technological developments, (3) the work of scientists, and (4) the nature of science (Abd-El-Khalick, 2002; Abell \& Lederman, 2007; Mamlok, 1997; National Research Council, 2011).

Curriculum materials should include scientific developments and historical analyses of scientific events, which will be taught by introducing the students to important events in the development of science and the work of scientists. A study conducted by Blumenfeld, Fishman, Krajcik, Marx, and Soloway (2000) showed that if science curriculum development takes into consideration cultural and social aspects, together with the related historical context, it helps in improving students' attitudes towards science and towards science learning. 


\section{Contemporary research approach}

Using contemporary research for chemistry teaching requires introducing cutting-edge scientific developments to high-school science lessons. This approach provides the students with an opportunity to learn about research development while it is still in the research laboratories (Blonder \& Sakhnini, 2016; Blonder, Joselevich, \& Cohen, 2010; Bryan \& Giordano, 2015). This includes reading primary literature that is adapted to their level (Yarden, 2009), meeting researchers and hearing them describe their research and learning from well-updated teachers who are familiar with contemporary research (Blonder \& Mamlok-Naaman, 2016; Kapon, Ganiel, \& Eylon, 2009). This approach allows the students to actually observe (1) the development of modern scientific knowledge; (2) authentic research that is conducted in the research labs nowadays; (3) who are currently the leading scientists and how they work; and (4) the nature of contemporary science.

\section{Why should chemistry be taught using the historical approach and the contemporary science approach?}

\section{Historical approach}

The National Science Education Standards (National Research Council, 1996) recommends that science educators should develop curriculum materials with a historical approach and explained:

"In learning science, students need to understand that science reflects its history and is an ongoing, changing enterprise. The standards for the history and nature of science recommend the use of history in school science programs to clarify different phases of scientific inquiry, the human aspects of science, and the role that science has played in the development of various cultures." (National Research Council, 1996).

It has been suggested that integrating historical and philosophical aspects into the science curricula should (1) enhance our understanding of the nature of science by future scientists as well as by future citizens (MamlokNaaman, Ben-Zvi, Hofstein, Menis, \& Erduran, 2005), and (2) help in coping with misconceptions and with alternative models that students develop (Nussbaum, 1985a,Nussbaum). The American Association for the Advancement of Science (1989) suggests that students may better understand the nature of science (the scientific methodology) if they will study according to a historical approach. Lederman, Abd-El-Khalick, Bell, and Schwartz (2002) claimed that integrating scientific developments into science studies may also help in understanding the work of scientists. Students who are acquainted with developments in science will be more aware of scientists' struggles during their work, and this may advance their understanding of the nature of science (Schwab, 1962).

In the last twenty-five years this approach has been adopted and the importance of the history of science in science teaching has been acknowledged by policy makers, educational researchers, and teacher educators (The American Association for the Advancement of Science, 1989; Matthews 1997; 2012; McComas, 1998). It is suggested, that using the historical approach may improve science teaching and learning (Duit \& Treagust, 2003). A number of different rationales and practical proposals have been made with the aim of acquainting prospective and in-service science teachers with appropriate themes. In the United States, for instance, suggestions for including the history of chemistry in chemistry teaching can be traced back to the 1930s (Jaffe, 1938).

\section{Contemporary research approach}

Dewey, John (1938), stated "If we teach today's students as we taught yesterday's, we rob our children of tomorrow." Dewey's well-known statement poses a challenge for science educators. This challenge can be addressed by the approach of learning science through contemporary research. According to this approach, contemporary research and cutting-edge knowledge should be part of the school science curriculum (Blonder, 2015). Learning science by integrating contemporary research provides students with an opportunity to receive upto-date information regarding what science actually is. Students realize that research concerns real people that look similar to them and share the same norms of the current era. They also learn about the open nature of scientific questions that await for a research-based solution (when searching in Google Scholar for "unsolved science mystery", one retrieves about 32,600 research papers). The nature of scientific questions involves an epistemological belief that incorporates the numerous sources and scope of knowledge (Luft \& Roehrig, 2007).

Contemporary research encompasses many fields and develops in many different directions. Therefore, in this paper we chose to focus on one example of contemporary scientific research - nanotechnology (Jones et al., 
2013) that will be reffered as NST (Nanoscale Science and Technology). We will therefore examine different aspects of this approach as they are reflected in nano-scale science and technology education.

\section{What can be taught using each approach?}

\section{Historical approach}

As mentioned above, it is very important for students to understand that science is not a given body of knowledge that was somehow received from heaven but rather, is an ever-developing body of knowledge. This can be achieved by following the development of the changes in our understanding of scientific developments from ancient times to the present as was presented in the teaching unit "Science: An-Ever Developing Entity" (Mamlok, 1997),

This teaching unit deals with concepts that refer to the structure of matter, developed according to "the spirit" of the era. It starts with Aristo's theory (the four elements) in ancient Greece, continues with the work of the alchemists who were desperately looking for ways to turn simple metals into gold, but worked according to Aristo's theory, and ends with $20^{\text {th }}$ century atomic models. By learning the unit (consisting of 30 periods), the students are exposed to the meaning of scientific models, and to the way in which our understanding of the structure of matter has developed. In addition, they learn how the scientific process has changed over the years, due to new data resulting from new experiments - data that could not be explained by Aristo's theory. Thus, there was a need to develop new models and new theories.

Mamlok-Naaman et al. (2005) referred to the "Modern alchemists" who succeed nowadays to change elements to other elements, but still, there is a need to consider the economic aspects. The alchemists did not succeed in turning simple metals into gold, but their experiments enabled them to develop new laboratory instruments and to discover new medications. Students should be taught to appreciate the work of the alchemists and their achievements, and to understand that they could not achieve their goal because they adopted Aristo's theory, which existed for many decades. Moreover, the alchemists behaved as a secret sect. The individual alchemists did not share their ideas with others, and could not get any feedback regarding their work. This might also be because there was no communication among the scientists at that time. The new scientific data, the development of the printing press, and new technologies ushered in the revolution in scientific models and theories. "If indeed, one can claim that children's understanding of scientific concepts develops in a way analogous to that of the knowledge of scientists throughout history, then introducing students to the steps of this development may help them to "grow up" with and appreciate science. In this way, they are not confronted with a temporary scientific way of thinking but instead, can start with their own picture of the world and can gradually reconcile it with what is acceptable nowadays. It is hoped that if this happens, students will feel less estranged and this will also be manifested in their attitudes towards science in general and also towards their science studies" (Mamlok-Naaman et al., 2005).

\section{Contemporary research approach}

When dealing with contemporary scientific topics, there is no existing tradition regarding what to teach. Usually at the beginning, sporadic teaching units are developed. These units present a partial view of a new field based on the knowledge of the developers. In nanotechnology, this can include, for example, units about AFM (Atomic Force Microscope) (Blonder, 2010; Blonder et al., 2010; Planinšič \& Kovač, 2008), units raising nanoethical questions (Berne \& Schummer, 2005; Schummer, 2007; Sweeney, 2006), units about a chosen concept (Blonder \& Sakhnini 2012; 2015; Bryan, Magana, \& Sederberg, 2015), and units about nanotechnology applications (Blonder \& Dinur, 2011; Hutchinson, Bodner, \& Bryan, 2011). Then, the new field receives attention from the scientific community for systematically identifying the basic concepts in the field that should be taught (Blonder \& Sakhnini, 2016).

In elementary schools: Huang, Hsu, and Chen (2011) from Taiwan attempted to find NST (Nanoscale Science and Technology) concepts that should be integrated into an elementary school curriculum. They identified five main nanotechnology core concepts suitable for elementary school science: "(1) nano-technology definitions, (2) nano-scale features, (3) nano-phenomena in the natural world, (4) nano-materials, and (5) the development of nanotechnology" (Blonder \& Sakhnini, 2016, p. 118). Intensive efforts regarding integration of nanotechnology in primary education was conducted in Greece in the Spyrou research group (e.g. Manou, Spyrtou, Hatzikraniotis, \& Kariotoglou, 2017). However, most of the research dealing with identifying basic NST concepts has been conducted at the high-school science level. 
At the high-school level: In Germany, the Model of Educational Reconstruction (MER) was applied (Parchmann \& Komorek, 2008). The identification process according to this model is dynamic; there is a live discussion, and the result is also based on learning theories MER (Blonder, Parchmann, Akaygun, \& Albe, 2014). This model combines content analyses, empirical research, and the design of educational settings. MER considers teachers' perspectives and experts' knowledge in order to develop a coherent educational program that takes into consideration scientific parameters as well as science education, as presented in Figure 1. Student teachers and experts in nanotechnology were chosen to analyze the learners' perspectives regarding nano-science, to investigate pre-service teachers' self-estimated knowledge, their expectations about teaching nano-science at the secondary school level, and their beliefs about nanostructures and about techniques such as scanning tunneling microscopy (STM) and atomic force microscopy (AFM). Preliminary results of this research showed that student teachers are interested in gaining further knowledge and advancing their understanding, but that they do not yet feel confident about teaching them.

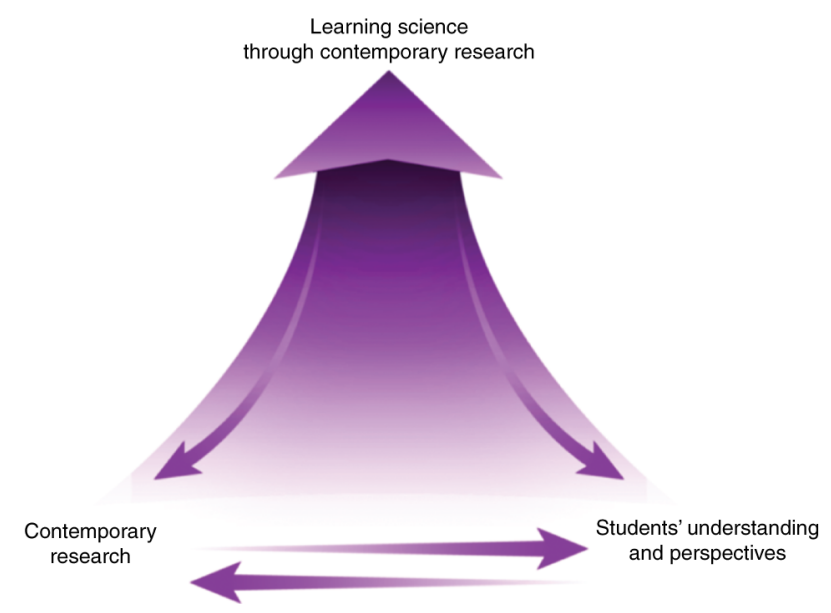

Figure 1: MER process for developing a coherent educational program in NST, adapted from Parchmann \& Komorek, 2008. Designed by Ziv Ariely.

The NSF in the US supported the development of the NST "big-ideas" document by Stevens, Sutherland, and Krajcik (2009); it resulted from two workshops involving both scientists and science educators. In order to include an interdisciplinary perspective, scientists and science educators from different scientific disciplines were chosen to reach a consensus regarding what constitutes the big ideas in NSE. Big ideas are core concepts that are critical and fundamental for understanding the basics of a field (namely, the field of nano-science). They also suggested how these ideas might be introduced into the US science curriculum. The nine big ideas are as follows: "(1) size and scale, (2) the structure of matter, (3) forces and interactions, (4) quantum effects, (5) size-dependent properties, (6) self-assembly, (7) tools and instrumentation, (8) models and simulations, and (9) science technology and society" (Stevens, et al., 2009).

A different methodology was applied in a study conducted in Israel (Sakhnini \& Blonder, 2015). A threeround Delphi methodology was applied to reach a consensus regarding the essential concepts that should be taught in high-school science. "Eight essential NST concepts were identified: (1) size-dependent properties, (2) innovations and applications of nanotechnology, (3) size and scale, (4) characterization methods, (5) functionality, (6) classification of nanomaterials, (7) fabrication approaches of nanomaterials, and (8) the making of nanotechnology." (Sakhnini \& Blonder, 2015). This study identified three NST concepts that had not yet been recognized in previous research (Blonder \& Sakhnini, 2016). This study was followed by an additional Delphi study to select nanotechnology applications recommended for the high-school level (Sakhnini \& Blonder, 2016). As a result, five nanotechnology applications were suggested by experts in nanotechnology and education experts: "(1) nanomedicine, (2) nanoelectronics, (3) photovoltaic cells, (4) nanobots, and (5) self-cleaning" (Sakhnini \& Blonder, 2016).

At the college level: Wanson et al. (2009) adapted the "big ideas" that were identified by Stevens et al. (2009) to the college level. They suggested that degree programs in Nanoscale science and engineering (NSE) should include four aspects or areas in NSE (P-N-P-A): "Processing (how nano-entities are fabricated), Nanostructure (how the structure of nano-entities can be imaged and characterized), Properties (the resulting size-dependent and surface-related properties of nanostructured materials/devices), and Applications (how nano-materials and nanodevices can be designed and engineered for the benefit of society)." (Wanson et al., 2009, p. 615). 


\section{How can chemistry be taught according to each of these approaches?}

\section{Historical approach}

Ben-Zvi (1999) claimed that students will be able to understand scientific concepts if they will learn them in a simple and uncomplicated way, namely, by conducting discussions and referring to relevant phenomena, and by using fewer calculations or formulas. Niaz and Rodriguez (2002) recommended focusing on controversial theories, and conducting classroom debates and experiments, which were carried out in different periods. Conant (1957), Brush (1974), and Irwin (1997) recommended elaborating on the "spirit" of the various periods the economical, political, and social aspects.

\section{Contemporary research approach}

Integrating contemporary research and development into a school chemistry curriculum is always challenging. The experts who develop contemporary knowledge and skills are not teachers, and teachers did not encounter the subject during their studies, since it was not yet known (Blonder, 2011; Drane, Swarat, Light, Hersam, \& Mason, 2009). This situation leads to a need for teachers' professional development that will prepare them for teaching contemporary scientific research in their classes. In the field of nanotechnology many courses were developed for teachers, and teachers' attitudes regarding the new field were examined (Blonder, 2011; Blonder et al., 2014; Bryan, Sederberg, Daly, Sears, \& Giordano, 2012; Gardner \& Jones, 2014; Gorghiu \& Gorghiu, 2012; Lin, Chen, Shih, Wang, \& Chang, 2015; Tomasik, Jin, Hamers, \& Moore, 2009). A situation in which new scientific knowledge is integrated into a science curriculum can bring with it numerous advantages. Curriculum developers must consider current learning theories regarding how people learn. Jones, Gardner, Falvo, and Taylor (2015) analyzed different kinds of thinking that are required for understanding different NST concepts. Children at different ages have different thinking abilities and therefore, different concepts should be taught at different age levels. (Jones et al. 2015). Other studies examined different learning environments for the teaching of specific NST concepts (Blonder \& Sakhnini, 2012, 2015). There is no need to replace a traditional pedagogy with a more appropriate one. The suitable pedagogy could be integrated in advance. For example, many studies were conducted that were related to students' difficulties in learning the concept "size and scale", a concept taught in biology, chemistry, and physics courses. It is very hard to realize how small nano actually is since students cannot feel with their own senses objects at this scale (Jones et al., 2007). Educational studies have shown that students can better understand small size and scale when they are taught it in comparison to objects with which they are familiar from their everyday life experiences (Jones et al., 2007, Jones et al., 2015).

In addition, when we integrate contemporary research into school chemistry classes, students can learn about the actual researcher who conducted the study. These meetings expose the students to the actual process of developing knowledge in science, as reflected from the eight NST essential concepts - the making of nanotechnology, introduced by Sakhnini and Blonder (2015). Different means are required to arrange meetings with active researchers. Students can participate in a scientific conference (Blonder \& Sakhnini, 2015) and can attend a researcher's lecture (Kapon et al., 2009). Modern technology can help to bring scientists to school via YouTube (Blonder et al., 2013) or on-line courses (Cohen, Blonder, Rap, \& Barokas, 2016).

\section{Three examples of teaching according to each approach}

In order to better demonstrate how each of the approaches is actually applied for teaching chemistry, three examples were chosen. The selected examples do not cover specific content in the science curriculum; they instead represent central issues in science education: (1) using and developing models (Boulter \& Buckley, 2000; Justi \& Gilbert, 2002a); (2) understanding the relationship between science and technology (Sjøberg \& Schreiner, 2005) and (3) understanding the nature of science (Abd-El-Khalick \& Lederman, 2000) We wish to emphasize that other examples could be presented as well. 


\section{Example 1. Model development}

\section{Historical approach}

The teaching unit "Science: an Ever-Developing Entity" (Mamlok, 1997) may serve as an example of the way in which the structure of matter has always been understood through models. The unit elaborates on the connection between the development of various models of the structure of matter, and the periods in which they were developed, as mentioned by Cramer (1979). It deals with concepts that refer to the structure of matter, developed according to "the spirit" of the era. It starts with Aristotle's theory (the four elements) in ancient Greece, continues with the work of the alchemists who were desperately looking for ways to turn simple metals into gold, but worked according to Aristotle's theory, and ends with $20^{\text {th }}$ century atomic models. By learning the unit (consisting of 30 periods), the students are exposed to the meaning of scientific models, and to the way in which our understanding of the structure of matter has developed. In addition, they learn how the scientific process has changed over the years, due to new data resulting from new experiments - data that could not be explained by Aristo's theory. Thus, there was a need to develop new models and new theories. In this way, students will be able to better understand how scientific developments interact with science and society (Elkana, 2000).

Scientific models are used in science as learning tools, as well as representations of abstract concepts and as consensus models of scientific theories. Changes and developments in scientific models are based on facts and the discovery of new facts / phenomena, and are not easily adopted by the scientific community (Mamlok, Ben-Zvi, Menis, \& Penick, 2000). Moreover, if both students and teachers understand the conceptual meaning as well as the aspects of models, it might reduce learning difficulties and misconceptions in chemistry, and help them in developing their own mental models of scientific concepts (De Jong, Blonder, \& Oversby, 2013; Erduran, 2001; Justi \& Gilbert, 2002a).

The teaching unit describes how "the Greek model survived for many centuries until evidence and knowledge from experimentation led to contradictory conclusions. The introduction of quantitative considerations into the chemistry laboratory brought about the revival of the atomic theory originally postulated by the Greeks. Matter, according to Dalton's $18^{\text {th }}$ century views, consisted of small, indestructible particles. Dalton's atoms were the basic units of this matter; hence, they could not be interchangeable. Since Dalton's theory was generally accepted, scientists concluded that one element could not be transformed into another. At this point the period of the ancient alchemists ended" (Mamlok-Naaman et al., 2005).

One of the experiments will serve as an example to the students' activities which are integrated in the module:

\section{Can iron be transmutted into copper?}

\section{Instructions}

- Place a piece of steel wool into a small beaker.

- Add blue solution to cover the steel wool.

- After a few minutes, remove the steel wool, using forceps.

\section{Questions:}

1. What happened to the steel wool?

2. In your opinion, what happened in this experiment?

3. Design an experiment to test your hypothesis.

This goal of this experiment is to convey the message, that the alchemists succeeded in producing various substances, but failed in turning base metals into precious metals such as gold by not searching a new theory which should replace, Aristotle's one. However, despite their failures, they developed important procedures in their work, including methods of compounds production, and experiments' performance, such as mixing, separating and filtering methods. 


\section{Contemporary research approach}

Contemporary research enables chemistry teachers and students to critique their knowledge by comparing it to new scientific results. The basic concepts of chemistry involve atoms and bonds but in teaching them, teachers usually build models to describe them. Since the days of Democritus' atom and Avogadro's molecule, scientists have longed to observe these fundamental building blocks of nature. This dream came true in 1981, with the invention of the scanning tunneling microscope (STM) (Binnig, Rohrer, Gerber, \& Weibel, 1982). The opportunity to use STM, and later on AFM (atomic force microscope) penetrated into science education. Margel, Eylon, and Scherz (2004) developed and studied a program in which students who learned about the particulate nature of matter in middle school chemistry were invited to the STM facility to actually visualize atoms. Blonder et al. (2010) described in their review other curricular subjects that can benefit from the use of STM or AFM. These instruments have very high resolution and in recent studies, they were able to show single molecules on a surface (Gross, Mohn, Moll, Liljeroth, \& Meyer, 2009), chemical bonds, and even hydrogen bonds (Zhang et al., 2013) as presented in Figure 2 and Figure 3. The abstract concept of chemical bonding can be visualized and can provide data for a class discussion about the differences between the model learned and the experimental data, for example, what are the characteristics of each? What can we learn from each?
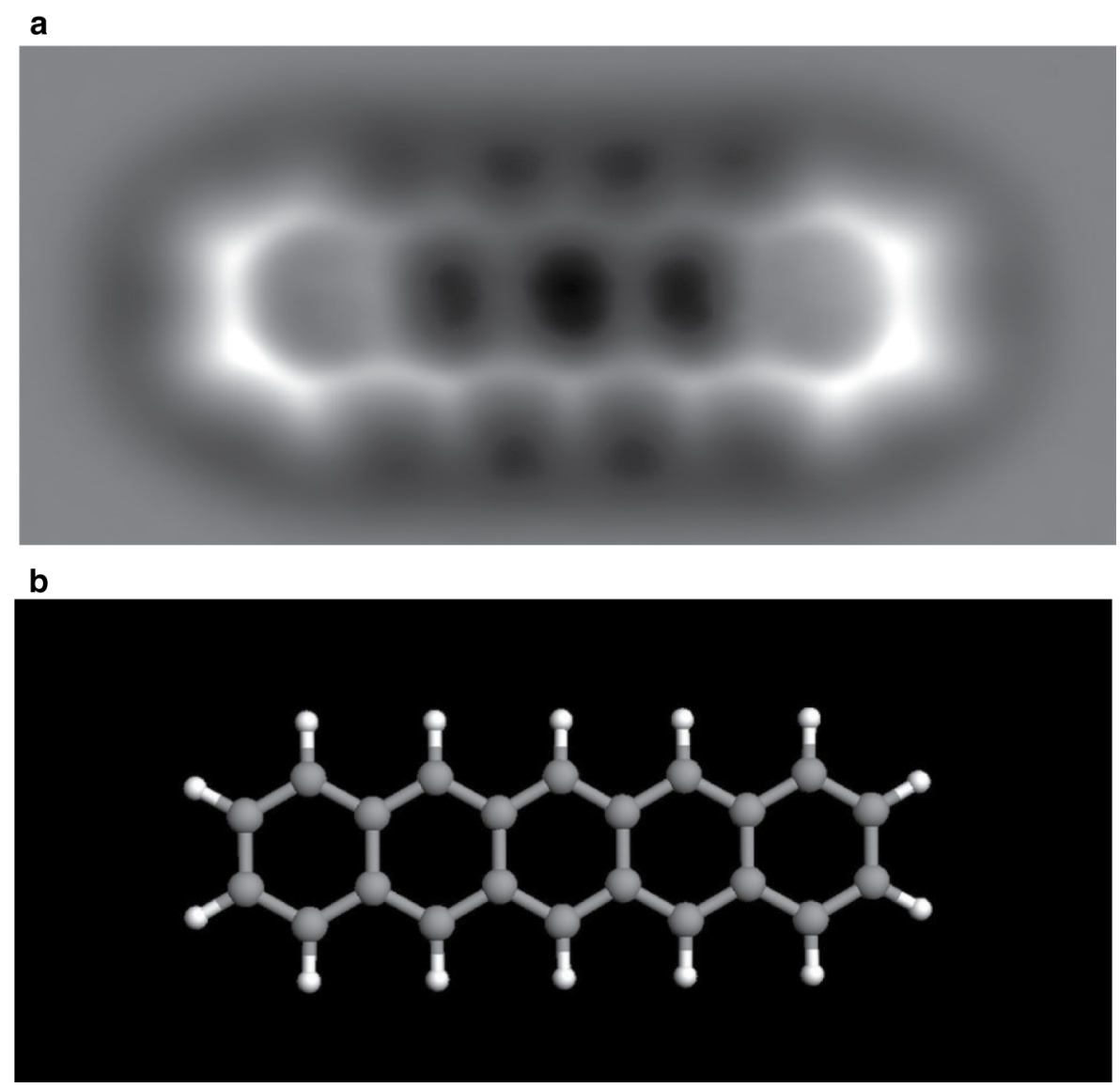

Figure 2: (a) AFM image of pentacene on $\mathrm{Cu}(111)$. (b) Ball-and-stick model of the pentacene molecule, which was obtained from Gross et al., 2009. License Number: 4602360082109, License date: Jun 05, 2019 

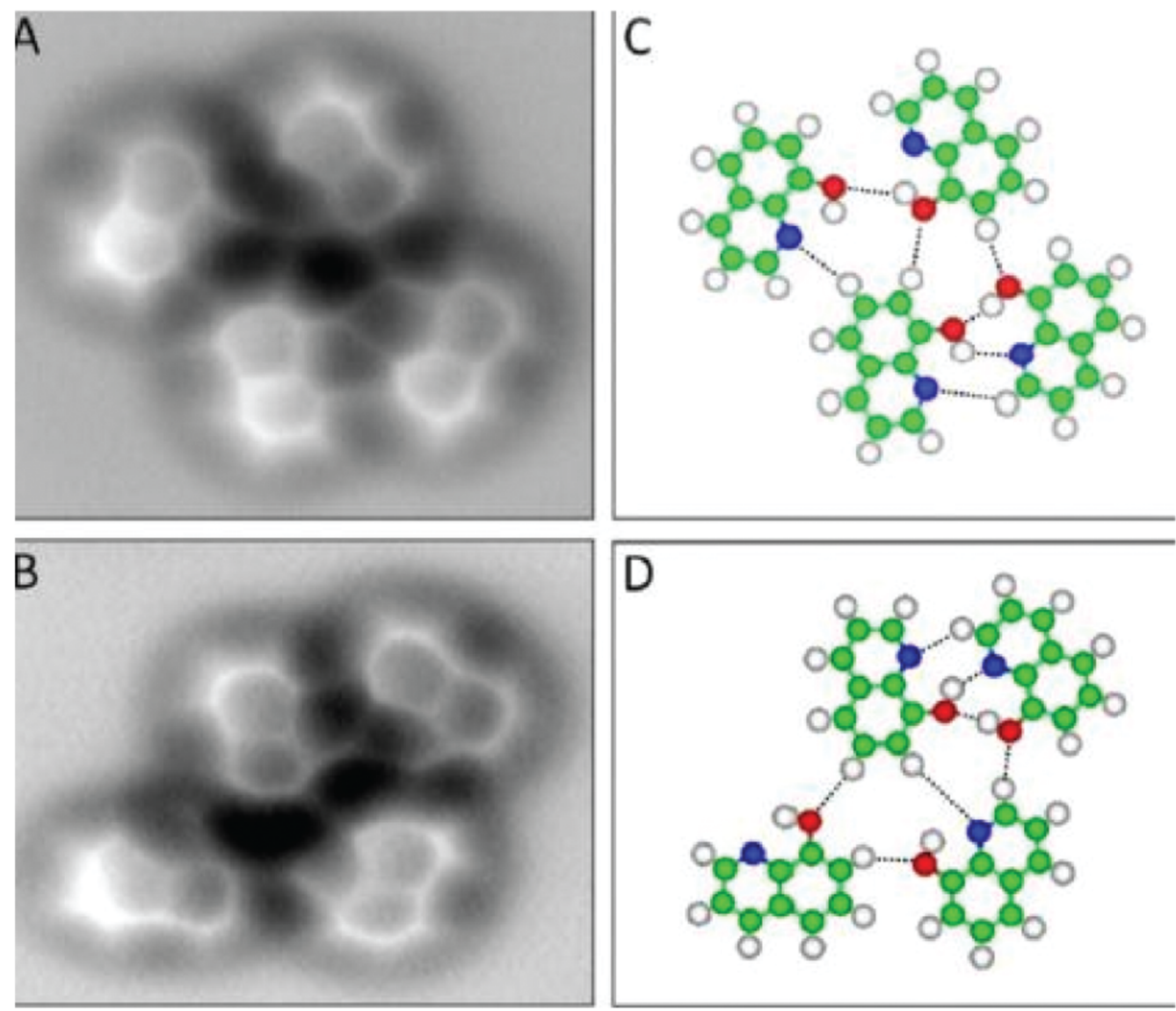

Figure 3: 8-hydroxyquinoline (8-hq) molecules adsorbed on the $\mathrm{Cu}(111)$ surface, which was obtained in Zhang et al., 2013. AFM measurements of 8-hq assembled clusters on $\mathrm{Cu}(111)$. (a) and (b) Constant-height frequency shift images of typical molecule-assembled clusters and their corresponding structure models (c and d). The dashed lines in (c) and (d) denote likely $\mathrm{H}$ bonds between 8-hq molecules. Green, carbon; blue, nitrogen; red, oxygen; white, hydrogen. License number: 4602351508832, License date: Jun 05, 2019

\section{Example 2. The nature of science (NOS)}

\section{Historical approach}

NOS is meta-knowledge about science that arises from the interdisciplinary reflections made by experts in the philosophy, history, and sociology of science, science educators, and by some scientists, but since the enterprise of science is multifaceted and dynamic, it is hard to precisely define the concept of NOS. Indeed, no consensus currently exists among these experts regarding one specific definition for NOS (Lederman, Antink, \& Bartos, 2014). Perhaps one of the reasons may be that there is an attempt to establish a set of features that are common to all science disciplines, i.e. to provide a holistic view of NOS (Erduran \& Dagher, 2014).

Over the last few years, research has been conducted to both diagnose prospective teachers' beliefs about NOS and compare them with the recommendations of papers on the reform of science teaching (e.g. GarcíaCarmona \& Acevedo, 2016) in order to promote a better understanding of NOS. There is no doubt that NOS should be appropriately incorporated into science teaching, but by itself, it is insufficient, since many general and specific factors influence its incorporation and its pedagogical effectiveness.

The critical and reflective reading of some newspaper articles with scientific content has great potential for addressing NOS in science classrooms (Cakmakci \& Yalaki, 2011; Shibley, 2003), but its educational efficacy has not yet been sufficiently assessed.

In any case, when prospective teachers begin teaching NOS, they need some specific benchmark to decide what NOS issues could be addressed in the school science curriculum. However, the establishment of such a benchmark is not without controversy in view of the continuous debates about it within the science education community (Allchin, 2011; Erduran \& Dagher, 2014; Matthews, 2012; Schwartz, Lederman, \& Abd-El-Khalick, 2012). Nevertheless, this controversy or discussion is understandable because of the multifaceted nature and 
complexity of science, which, over the last few decades, have given rise to diverse proposals on what NOS is and what aspects of it should be taught (Duschl \& Grandy, 2013; García-Carmona \& Acevedo, 2016).

The following will serve as an example to one of the high school assignments regarding NOS:Students were asked to write an essay focusing on scientists and their discoveries, entitled "The Person behind the Scientific Endeavor". In order to help students in writing an essay about "The Person behind the Scientific Endeavor", the teachers introduced them to the biographies of numerous eminent scientists from different periods. These scientists developed scientific theories that often contradicted those that had been previously. The students were asked to describe in detail the lives of these scientists and the discoveries made by them. They also produced work characterizing "their" scientists: a picture of the scientist accompanying an article that the students had written. The students used internet resources, and the teachers helped them with references dealing with the history of science. Afterwards, the class constructed a display along a time-line in order to place events, scientists, and theories in their appropriate historical perspective. Thus, all the students felt that each scientist represented by them had been given an honorable place in the history of science (Mamlok et al., 2000).

\section{Contemporary research approach}

If we wish to transmit to students a real image of the nature of science and convey the way scientists actually work, we should provide students with the opportunity to encounter a modern, realistic image of science. Scientists today work in interdisciplinary groups and use tools and perspectives from other disciplines to solve contemporary problems (Kähkönen, Laherto, Lindell, \& Tala, 2016). Scientists today work with advanced instruments (Blonder, Mamlok-Naaman, \& Hofstein, 2008; Blonder et al., 2010; Schwarzer, Akaygün, Sagun-Goko, Anderson, \& Blonder, 2015). They participate in prestigious conferences and communicate their ideas (Blonder \& Sakhnini, 2015; Laherto, Tirre, Parchmann, Kampschulte, \& Schwarzer, 2018). Incorporating modern scientific topics provides an opportunity to expose students to these sides of science that they are not familiar with and are far from the image of the genius scientist with which they cannot identify. Sakhnini and Blonder identified the NST essential concepts "the making of nanotechnology" (Blonder \& Sakhnini, 2015; Sakhnini \& Blonder, 2015). This concept is defined as "revealing the mystery of nanotechnology, or in other words, how nanoscience research is performed and how innovations are transformed into applications. This concept has three sub-concepts: multidisciplinary science and technology, team work, and the development of nanotechnology." (Sakhnini \& Blonder, 2015). This concept reflects the importance of exposing the students to an authentic environment and to activities that are well beyond the scientific facts and the experimental results. Students who participated in a nanotechnology scientific conference changed their perceptions regarding the image of the scientist as a result of meeting real scientists at the conference (Blonder \& Sakhnini, 2015).

Moreover, when we expose students to modern science, the understanding of which is not all known, part of the nature of science reflects its ever-developing nature. Students realize that there are still open-ended questions. This message is a call for future scientists to join the research and be the next scientist who will explore new areas and find answers to the unsolved questions.

\section{Example 3. The relationship between science and technology}

\section{Historical approach}

Past ethical dilemmas are also discussed with regard to the roles of science and technology. People tend to blame science for all the disasters (real or imagined), when really what is to be blamed is the manner in which science, i.e. technology, is used. Another thing that should be understood is that since the beginning of time, science and technology have been linked together. Developments in advancing our understanding of the world, in turn, enable the development of new technologies, and the introduction of new equipment opens the door to new ways of thinking. For example, developing more accurate balances enabled quantitative considerations that led to the revival of atomic theory. However, theoretical developments of the atomic model enabled the wide use of electricity from conventional power plants, and later the development of nuclear ones.

\section{Contemporary research approach}

Usually basic science is perceived as the knowledge provider for the development of new technology. The revealing of new nano-materials with novel properties led to the development of novel applications in many 
fields. However, in nano-science the development of high-resolution microscopies such as AFM, STM and electron microscopies enabled scientists to actually see the nano-materials and the nanostructures they created in research labs. The observation of these products deepened scientists' understanding of the particles at the nanoscale and resulted in increased research work and the development of the nano-science and nanotechnology field (Blonder et al., 2010).

The relationship between science and society has received much attention when dealing with contemporary research (Owen, Macnaghten, \& Stilgoe, 2012). The European commission emphasizes the importance of responsible research and innovation (RRI) values (Sutcliffe, 2011) and several programs for the development of science education programs that integrate RRI into science education were developed and implemented in Europe (e.g. Blonder, Zemler, \& Rosenfeld, 2016). These programs bring to science lessons contemporary research, together with possible ethical dilemmas and environmental influences, which are discussed in class (Apotheker et al., 2016).

\section{Students' motivation and attitudes: the influence of each approach}

\section{Historical approach}

Contrary to the situation at the beginning of the $19^{\text {th }}$ century, when science was viewed as important, interesting, and exciting, the image of science today is rather negative. It is therefore reasonable to assume that this lack of interest can hinder students' motivation to become involved in science learning. A few studies show that students' perception of chemistry concepts is influenced by their motivation, and they learn only when they want to (Fairbrother, 2000).

Based on studies regarding the use of the historical approach (Abd-El-Khalick, 2002; Erduran, Aduriz-Bravo, \& Mamlok-Naaman, 2007), we believe that students' motivation to learn chemistry or other scientific disciplines will increase, since they will be exposed to various projects of scientists from a variety of cultures, which will enable them to better understand the scientific methodology and thinking.

One of the students who were exposed to the historical approach in chemistry class said:

"I did not like to study science, since I could not understand the meaning of many concepts. For example: the concept of energy and its scientific explanations did not mean anything to me. However, when we started to learn about the Phlogiston theory, it interested me. According to the Phlogiston theory, if something burns, it means that it consists of a material that enables it to burn. This material was called Phlogiston, meaning: creator of flames. Today we know about the existence of oxygen, which is "responsible" for a burning reaction, but then, people did not know about it. In my opinion, the Phlogiston theory made sense and was not ridiculous. Today we use the "energy" concept, but do people really know how to explain it?". (Mamlok-Naaman et al., 2005).

The change in students' attitudes towards science in general, and towards chemistry learning in particular, was investigated in a study conducted with students who studied the "Structure of Matter" using a historical approach (Mamlok-Naaman et al., 2005). At the beginning of the study, the students had negative attitudes towards science and science and chemistry learning. During the study, however, they gradually changed their attitudes. At the end of the study, one of the students claimed that he stopped turning off the television when it showed a scientific program. Other students said that their self-efficacy increased, and that they were no longer afraid about not being able to cope with chemistry problems. They also mentioned that the variety of teaching strategies that were used by their teachers during these lessons improved their understanding of the subject and enhanced their interest and motivation.

\section{Contemporary research approach}

On the other hand, the idea that teaching topics such as nanotechnology could be appealing for young students is based on science educational research. Several studies found that teaching nanotechnology increases students' motivation to pursue science studies and scientific careers. Hutchinson et al. (2011) investigated middleschool students' interest and motivation in nano-science concepts and phenomena. To this end, students were introduced to several nano-scale topics and phenomena through four manipulative activities and a series of nano-scale driving questions. They found that students were most interested in NST topics that related to their "real world" and daily lives.

Delgado, Stevens, Shin, and Krajcik (2015) developed a 12-hour instructional unit for size and scale, in a summer science camp. The nanotechnology context influenced the students significantly and increased their 
knowledge about the size of objects. They became more involved and interested because the context was relevant to students' daily lives. Blonder and Dinur (2011) conducted a study focusing on teaching students about the nanotechnology application of LEDs (light-emitting diodes). They found that the number of students who chose to enroll in an advanced chemistry lesson in school increased as a result of learning about LEDs. In a different study, similar results were obtained (Blonder \& Sakhnini, 2012). In a longitudinal study that summarized the professional development of chemistry teachers that designed a teaching module in nanotechnology and evaluated it in their class, most of them reported that the integration of nanotechnology elevated students' motivation to learn chemistry (Blonder \& Mamlok-Naaman, 2016).

Note that nanotechnology elevates both male and female students' motivation to pursue science careers and does not create a gender gap (Srisawasdi, 2015). We can feel the enthusiasm of a junior high-school student saying, "We actually saw atoms with our own eyes!" (Margel et al., 2004) and realize the motivational influence of modern science on students.

\section{Discussion}

Since any suggested approach for chemistry education should be initiated by the chemistry teachers, we will refer to teacher's perspectives as an organizing framework for the discussion.

Teachers need to undergo suitable preparation when trying to implement each of the two approaches. Regarding integrating the contemporary research topic into school chemistry, teachers who completed their formal education before the development of the new field do not have the necessary content knowledge in order to integrate a modern field into their teaching. As already mentioned, in the context of the historical approach, Arons (1984) claimed that many chemistry teachers do not devote enough time to discuss the nature of the scientific process and, as a result, miss opportunities to instill critical and investigative thinking skills.

\section{Historical approach}

Schwab (1962) argued that expertise in teaching requires both knowledge of the content of a domain and knowledge about the epistemology of that domain. Teachers develop the requisite capability of transforming a subject into teachable content only when they know how the disciplinary knowledge is structured. Numerous studies (e.g. Lampert, 1990; Shulman, 1987) have illustrated the centrality of disciplinary knowledge to good teaching. The challenge facing teachers' education is that teachers in general have had little exposure to issues involving pedagogical knowledge beyond content knowledge.it should be noted that many times the teachers or the book begins with a brief history of but this is usually done in an encyclopedic style, whereby knowledge is presented as information without establishing the needed conceptual basis. Studies in the literature (e.g. Toulmin \& Goodfield, 1962) show how that without the availability of well-prepared teaching materials tailored for teachers there is little chance that the goal will be achieved on the large scale of the teacher education programs. This need concerns the area of the general philosophy and history of science as well as to the area of the philosophy and history of specific disciplines. The teaching materials could be better prepared by having historians and philosophers of science work together with teacher educators. According to many studies (Abimbola, 1983; Gil-Pérez, 1993; Izquierdo, 2000; Leach, 2001), science teacher education requires explicitly selecting particularly powerful elements. Choosing those elements and discarding other less interesting or useful ones would ensure that this meta-theoretical component is incorporated into teachers' thinking and practice.

The available theoretical developments along this line generally point to the need to identify a functional, useful framework for chemistry teaching. Authors usually select frameworks, topics, and concepts pertaining to well-known philosophical views (e.g. rationalism, hypothetico-deductivism, revolutionism, and constructivism) and seek appropriate frameworks for these pedagogies and methodologies suitable for teachers. To exemplify this practice, following a critical review during the 1990s of the extensive use of constructivism in science education, some authors have highlighted the urgent need to review with teachers the moderate, critical versions of realism and rationalism, along with the aims of a liberal science education for all (Giere, 1999; Good \& Shymansky, 2001; Matthews, 1997).

Nature-of-science (NOS) is one of the important topics in science education in general, and in chemistry education in particular (Erduran, Kaya, \& Dagher, 2017). However, NOS proposals addressed to teachers typically select general topics from the nature of science for which there is a reasonable consensus among researchers. For instance, the scientific method, changes in theory, realism, contexts, scientific explanation, and theory-ladenness are themes that have received increased popularity among science educators. These proposals infuse such topics into activities using various strategies (for a broad range of strategies, see McComas, 1998). For instance, a number of authors have turned to Giere (1988) decisional model of scientific judgment in order 
to design nature-of-science activities for prospective and in-service science teachers (Duschl, 1990; Izquierdo, 2000; Izquierdo \& Adúriz-Bravo, 2003; Jiménez Aleixandre, 1996). Some of these activities select and discuss famous episodes stemming from Giere's ideas.

\section{Contemporary research approach}

In discussing the integration of the contemporary research topic, we should refer to several challenges: the content challenge, the teachers' beliefs in their abilities to learn and later on to teach advanced modern science (self-efficacy beliefs), and the stage at which teachers need to adapt the new topic to their classes. When we designed an advanced course on nanotechnology (Blonder, 2011) the teachers were able to succeed in a knowledge test. However, they felt that their understanding of nanotechnology was not deep enough in order to teach the contents to their students (Blonder, 2010). In order to bridge this gap, we developed and implemented a threestage model to support teachers' learning of the contemporary contents and the adaptation of the contents to their classes (Mamlok-Naaman, Blonder, \& Hofstein, 2010). Importantly, we found that the model produced a better environment in which the teachers were able to develop their content knowledge, their efficacy-belief to achieve deep comprehension, and to adapt the contents to their classes.

In addition to this challenge, we have found several opportunities when introducing contemporary topic to teachers. The modern contents renew teachers' enthusiasm towards the subject they teach (Blonder, 2011) and they are able to transfer this enthusiasm to their students. The teachers participate in professional development courses to study the latest content. These courses provide an opportunity to use non-traditional teaching methods while teaching the new contents. We have found that teachers adapt these non-traditional teaching approaches when they teach about nanotechnology. This finding is reasonable since teachers tend to teach in the same way that they were taught. As Putnam and Borko (2000) explained: "How a person learns a particular set of knowledge and skills, and the situation in which a person learns, become a fundamental part of what is learned." (Putnam \& Borko, 2000). However, we also found that teachers transfer alternative teaching approaches (such as using a teaching model, integrating videos, using a student-centered pedagogy, and having students create and present a poster exhibition) to other topics in the science curriculum. This transfer was found to be sustainable over the course of five years (Blonder \& Mamlok-Naaman, 2016).

\section{Summary}

We believe that both ways of teaching and learning - either through contemporary research or by using a historical approach - should be integrated into the chemistry curriculum, and that teachers should be acquainted with both of them. This is acoed in a current study that compared the conceptual understanding of gas properties of students who learned in the historical or the contemporary context did not find any significant difference between the two groups (Milanovic \& Trivic, 2017). As mentioned, each approach: (1) deals with elements essential to chemistry education, e.g. the development of models, the relationship between science and technology, or the nature of science, (2) has its own uniqueness and contribution to chemistry education, and (3) complements the other one, by presenting the succession of the development of science in general, and of chemistry in particular. We suggest that teachers should be acquainted with the contemporary research approach as well as with the historical one. However, as mentioned, teachers should undergo an intensive and comprehensive preparation before implementing one or both of the approaches. They should receive proper guidance and support regarding what to teach, and how to teach while referring to the historical aspects or to contemporary research.

Here, different aspects of comparing two different approaches for chemistry teaching have been covered. However, there are additional dimensions that were not discussed here that are relevant for the comparison, e.g. the philosophy of science (Matthews, 2015) and the domain-specific philosophy of the chemistry (Erduran et al., 2007; Erduran \& Dagher, 2014). Another dimension that was mentioned briefly, and needs more attention, is the epistemological beliefs of science teachers and students, which can be developed by the two approaches. We hope that other researchers who find the discussion relevant to their research in science education will contribute to this important topic. 


\section{References}

Abd-El-Khalick, F. (2002). Rutherford's enlarged: A content-embedded activity to teach about the nature of science. Physics Education, 37, 64-68.

Abd-El-Khalick, F., \& Lederman, N. G. (2000). The influence of history of science courses on students' views of nature of science. Journal of Research in Science Teaching, 37, 1057-1095.

Abell, S. K., \& Lederman, N. G. (2007). Handbook of Research on science education. Mahwah, N]: Lawrence Erlbaum Associates.

Abimbola, I. O. (1983). The relevance of the "new" philosophy of science for the science curriculum. School Science and Mathematics, 83, 181192.

Allchin, D. (2011). Evaluating knowledge of the nature of (whole) science. Science Education, 95, 518-542.

American Association for the Advancement of Science. (1989). Science for all Americans, project 2061. New York: Oxford University Press.

Apotheker, J., Blonder, R., Akaygun, S., Reis, R., Kampschulte, L., \& Laherto, A. (2016). Responsible research and innovation in secondary school science classrooms: Experiences from the project Irresistible. Pure and Applied Chemistry, 89, 211-219.

Arons, A. B. (1984). Education through science. Journal of College Science Teaching, 13, 210-220.

Ben-Zvi, R. (1999). Non-science oriented students and the second law of thermodynamics. International Journal of Science Education, 21(12), 1251-1267.

Berne, R. W., \& Schummer, J. (2005). Teaching societal and ethical implications of nanotechnology to engineering students through science fiction. Bulletin of Science, Technology \& Society, 25(6), 459-468.

Binnig, C., Rohrer, H., Gerber, C., \& Weibel, E. (1982). Surface studies by scanning tunneling microscopy. Physical Review Letters, 49(1), 57-61.

Blonder, R. (2010). The influence of a teaching model in nanotechnology on chemistry teachers' knowledge and their teaching attitudes. Journal of Nano Education, 2, 67-75.

Blonder, R. (2011). The story of nanomaterials in modern technology: An advanced course for chemistry teachers. Journal ofChemical Education, 88, 49-52.

Blonder, R.(2015). “Chemistry of tomorrow” should be part of the school chemistry of today. EC2E2N NewsLetter, 16(1), 1-4.

Blonder, R., \& Dinur, M. (2011). Teaching nanotechnology using student-centered pedagogy for increasing students' continuing motivation. Journal of Nano Education, 3, 51-61.

Blonder, R., \& Sakhnini, S. (2012). Teaching two basic nanotechnology concepts in secondary school by using a variety of teaching methods. Chemistry Education Research and Practice, 13, 500-516.

Blonder, R., \& Sakhnini, S. (2015). The making of nanotechnology: Exposing high-school students to behind-the-scenes of nanotechnology by inviting them to a nanotechnology conference. Nanotechnology Reviews, 4(1), 103-116.

Blonder, R., \& Mamlok-Naaman, R. (2016). Learning about teaching the extracurricular topic of nanotechnology as a vehicle for achieving a sustainable change in science education. International Journal of Science and Mathematics Education, 14, 345-372.

Blonder, R., \& Sakhnini, S. (2016). What are the basic concepts of nanoscale science and technology (NST) that should be included in NST educational programs. In K. Winkelmann \& B. Bhushan (Eds.), Clobal perspectives of nanoscience and engineering education ( $\mathrm{pp}$. 117-127). AC Switzerland: Springer International Publishing.

Blonder, R., Mamlok-Naaman, R., \& Hofstein, A. (2008). Analyzing inquiry questions of high-school students in a gas chromatography openended laboratory experiment. Chemistry Education Research and Practice, 9, 250-258.

Blonder, R., Joselevich, E., \& Cohen, S. R. (2010). Atomic force microscopy: Opening the teaching laboratory to the nanoworld. Journal of Chemical Education, 87(12), 1290-1293.

Blonder, R., Jonatan, M., Bar-Dov, Z., Benny, N., Rap, S., \& Sakhnini, S. (2013). Can You Tube it? Providing chemistry teachers with technological tools and enhancing their efficacy beliefs. Chemistry Education Research and Practice, 14, 269-285.

Blonder, R., Parchmann, I., Akaygun, S., \& Albe, V. (2014). Nanoeducation: Zooming into teacher professional development programs in nanotechnology in four European countries. In C. Bruguière, A. Tiberghien, \& P. Clément (Eds.), Topics and trends in current science education (Vol. 1, pp. 159-174). Pintforce, the Netherlands: Springer.

Blonder, R., Zemler, E., \& Rosenfeld, S. (2016). The story of lead: A context for learning about responsible research and innovation (RRI) in the chemistry classroom. Chemistry Education Research and Practice, 17, 1145-1155.

Blumenfeld, P. C., Fishman, B. J., Krajcik, J. S., Marx, R. W., \& Soloway, E. (2000). Creating usable innovations in systemic reform: Scaling-up technology - embedded project-based science in urban schools. Education Psychologist, 35, 149-164.

Boulter, C. J., \& Buckley, B. C. (2000). Constructing a typology of models for science education. In J. K. Gilbert \& C. J. Boulter (Eds.), Developing models in science education (pp. 41-57). Netherlands: Kluwer Academic Publisher.

Brush, S. G. (1974). Should the history of science be rated? Science, 184, 1164-1172.

Bryan, L. A., \& Giordano, N. J. (2015). Special issue on Pre-college nanoscale science, engineering, and technology learning. Nanotechnology Reviews, 4(1), 1-6.

Bryan, L. A., Sederberg, D., Daly, S., Sears, D., \& Ciordano, N. (2012). Facilitating teachers' development of nanoscale science, engineering, and technology content knowledge. Nanotechnology Reviews, 1, 85-95.

Bryan, L. A., Magana, A. J., \& Sederberg, D. (2015). Published research on pre-college students' and teachers' nanoscale science, engineering, and technology learning. Nanotechnology Reviews, 4(1), 7-32.

Cakmakci, G., \& Yalaki, Y. (2011). Popular media as a tool for teaching science and its nature, in promoting students (Ed.), Teachers' Ideas about Nature of Science through Popular Media. Ankara: Hacettepe University: S-TEAM project.

Cohen, S., Blonder, R., Rap, S., \& Barokas, J. (2016). Online nanoeducation resources. In K. Winkelmann \& B. Bhushan (Eds.), Global perspectives of nanoscience and engineering education (pp. 171-194). AC Switzerland: Springer International Publishing.

Conant, J. B. (1957). Harvard case histories in experimental sciences (Vols. 1 \& 2). Cambridge, MA: Harvard University Press.

Cramer, F. (1979). Fundemental complexity. Interdisciplinary Science Reviews, 4, 132-139. 
De Jong, O., Blonder, R., \& Oversby, J. P. (2013). How to balance chemistry education between observing of phenomena and thinking in models. In I. Eilks \& A. Hofstein (Eds.), Chemistry Education: A practical guide and textbook for teachers, teacher trainees and student teachers (pp. 97-126). Rotterdam: Sense.

Delgado, C., Stevens, S. Y., Shin, N., \& Krajcik, J. (2015). A middle school instructional unit for size and scale contextualized in nanotechnology. Nanotechnology Reviews, 4(1), 51-69.

Dewey, John. (1938). Experience and education, a touchstone book. Simon \& Schuster.

Drane, D., Swarat, S., Light, G., Hersam, M., \& Mason, T. (2009). An evaluation of the efficacy and transferability of a nanoscience module. Journal of Nano Education, 1, 8-14.

Duit, R., \& Treagust, D. F. (2003). Students' conceptions and constructivist teaching approach. In B. J. Fraser \& H. J. Walberg (Eds.). Improving science education (pp. 49-69). Chicago, Illinois: University of Chicago Press.

Duschl, R. (1990). Restructuring science education. The importance of theories and their development. New York: Teachers College Press.

Duschl, R. A., \& Grandy, R. (2013). Two views about explicitly teaching nature of science. Science \& Education, 22, 2109-2139.

Elkana, Y. (2000). Science, philosophy of science and science teaching. Science \& Education, 9, 463-485.

Erduran, S. (2001). Philosophy of chemistry: an emerging field with implications for chemistry education. Sci Educ, 10(6), 581-593.

Erduran, S., \& Dagher, Z. (2014). Reconceptualizing the nature of science for science education: Scientific knowledge, practices and other family categories. Dordrecht, The Netherlands: Springer.

Erduran, S., Aduriz-Bravo, A., \& Mamlok-Naaman, R. (2007). Developing epistemologically empowered teachers: Examining the role of philosophy of chemistry in teacher education. Science \& Education, 16, 975-989.

Erduran, S., Kaya, E., \& Dagher, Z. (2017). From lists in pieces to coherent wholes: Revisiting the nature of science in science education. In ]. Yeo, T. W. Teo, \& K. S. Tang (Eds.), Research and practice in the Asia-Pacific region. Dordrecht, The Netherlands: Springer.

Fairbrother, R. W. (2000). Strategies for learning. In M. Monk \& J. Osborne. (Eds.), Cood practice in science teaching, (pp. 7-24). Philadelphia: Open University.

García-Carmona, A., \& Acevedo, J. A. (2016). Learning about the nature of science using newspaper articles with scientific content: A study in initial primary teacher education. Science \& Education, 25, 523-546.

Gardner, G., \& Jones, M. G. (2014). Exploring pre-service teachers' perceptions of the risks of emergent technologies: Implications for teaching and learning. Journal of Nano Education, 6, 39-49.

Giere, R. (1988). Explaining science. A cognitive approach. Minneapolis: University of Minnesota Press.

Giere, R. (1999). Del realismo constructivo al realismo perspectivo, Enseñanza de las Ciencias, extra issue, pp. 9-13.

Gil-Pérez, D. (1993). Contribución de la Historia y de la Filosofía de las Ciencias al Desarrollo de un Modelo de Enseñanza/Aprendizaje como Investigación. Enseñanza de las Ciencias, 12, 154-164.

Cood, R., \& Shymansky, J. (2001). Nature-of-science literacy in benchmarks and standards: Post-modern/relativist or modern/realist? Science and Education, 10, 173-185.

Corghiu, L. M., \& Gorghiu, G. (2012). Teachers' perception related to the promotion of nanotechnology concepts in Romanian science education. Procedia-Social and Behavioral Sciences, 46(0), 4174-4180.

Gross, L., Mohn, F., Moll, N., Liljeroth, P., \& Meyer, G. (2009). The chemical structure of a molecule resolved by Atomic Force Microscopy. Science, 325(5944), 1110-1114.

Huang, C. Y., Hsu, L. R., \& Chen, H. C. (2011). A study on the core concepts of nanotechnology for the elementary school. Journal of National Taichung University: Mathematics, Science \& Technology, 25, 1-22.

Hutchinson, K., Bodner, G. M., \& Bryan, L. A. (2011). Middle-and high-school students' interest in nanoscale science and engineering topics and phenomena. Journal of Pre-College Engineering Education Research, 1(1), 30-39.

Irwin, J. (1997). Theories of burning: A case study using a historical perspective. School Science Review, 78(285), 31-37.

Izquierdo, M. (2000). Fundamentos epistemológicos. In F. J. Perales \& P. Cañal (Eds.), Didáctica de las ciencias experimentales. Teoría y Práctica de la Enseñanza de las Ciencias (pp. 35-64), Alcoy: Marfil.

Izquierdo, M., \& Adúriz-Bravo, A. (2003). Epistemological foundations of school science. Science Education, 12, 27-43.

Jaffe, B. (1938). The history of chemistry and its place in the teaching of chemistry. Journal of Chemical Education, 15, 383-389.

Jiménez Aleixandre, M. P. (1996). Dubidar para aprender. Vigo: Edicións Xeráis.

Jones, M. G., Taylor, A., Minogue, J., Broadwell, B., Wiebe, E., \& Carter, C. (2007). Understanding scale: Powers of ten. Journal of Science Education and Technology, 16(2), 191-202.

Jones, M. C., Blonder, R., Gardner, C. E., Albe, V., Falvo, M., \& Chevrier, J. (2013). Nanotechnology and nanoscale science: Educational challenges. International Journal of Science Education, 35, 1490-1512.

Jones, M. G., Gardner, G. E., Falvo, M., \& Taylor, A. (2015). Precollege nanotechnology education: A different kind of thinking. Nanotechnology Reviews, 4(1), 117-127.

Justi, R. S., \& Cilbert, J. K. (2002a). Modelling, teachers' views on the nature of modelling, and implications for the education of modellers. International Journal of Science Education, 24(4), 369-387.

Kähkönen, A. L., Laherto, A., Lindell, A., \& Tala, S. (2016). Interdisciplinary nature of nanoscience: Implications for education In K. Winkelmann \& B. Bhushan (Eds.), Global perspectives of nanoscience and engineering education (pp. 35-82). AC Switzerland: Springer International Publishing.

Kapon, S., Ganiel, U., \& Eylon, B. S. (2009). Explaining the unexplainable: Translated scientific explanations (TSE) in public physics lectures. International Journal of Science Education, 32(2), 245-264.

Laherto, A., Tirre, F., Parchmann, I., Kampschulte, L., \& Schwarzer, S. (2018). Scientists' perceptions on the nature of nanoscience and its public communication. Problems of education in the 21st century (Spausdinta), 76(1), 43-57.

Lampert, M. (1990). When the problem is not the question and the solution is not the answer: mathematical knowing and teaching. Am Educ Res ], 27(1), 29-63.

Leach, J. (2001). Epistemological perspectives in science education research. In D. Psillos (Ed.) Science education research in the knowledge based society (vol. I, pp 13-15). Thessaloniki: Aristotle University. 
Lederman, N. G., Abd-El-Khalick, F., Bell, R. L., \& Schwartz, R. S. (2002). Views of nature of science questionnaire: Toward valid and meaningful assessment of learners conceptions of nature of science. Journal of Research in Science Teaching, 39, 497-521.

Lederman, G. L., Antink, A., \& Bartos, S. (2014). Nature of science, scientific inquiry, and socio-scientific issues arising from genetics: A pathway to developing a scientifically literate citizenry. Science \& Education, 23, 285-302.

Lin, S.-F., Chen, J.-Y., Shih, K.-Y., Wang, K.-H., \& Chang, H.-P. (2015). Science teachers' perceptions of nanotechnology teaching and professional development: A survey study in Taiwan. Nanotechnology Reviews, 4(1), 71-80.

Luft, J. A., \& Roehrig, G. H. (2007). Capturing science teachers' epistemological beliefs: The development of the teacher beliefs interview. Electronic Journal of Science Education, 11 (2), 38-63.

Manou, L., Spyrtou, A., Hatzikraniotis, E., \& Kariotoglou, P. (2017). Primary teachers' conceptions about the content of nanoscience-nanotechnology. Paper presented at the 3rd Int. Conf "Education Across Borders", Bytola.

Mamlok, R. (1997). Science: An ever-developing entity. Rehovot, Israel: Weizmann Institute of Science (in Hebrew).

Mamlok, R., Ben-Zvi, R., Menis, J., \& Penick, J. E. (2000). Can simple metals be transmuted into gold? Teaching science through a historical approach. Science Education International, 11(3), 33-37.

Mamlok-Naaman, R., Ben-Zvi, R., Hofstein, A., Menis, ]., \& Erduran, S. (2005). Influencing students' attitudes towards science by exposing them to a historical approach. International Journal of Science and Mathematics Education, 3(3), 485-507.

Mamlok-Naaman, R., Blonder, R., \& Hofstein, A. (2010). Providing chemistry teachers with opportunities to enhance their knowledge in contemporary scientific areas: A three-stage model. Chemistry Education Research and Practice, 11, 241-252.

Margel, H., Eylon, B., \& Scherz, Z. (2004). “We actually saw atoms with our own eyes”. Conceptions and convictions in using the scanning tunneling microscope in junior high school. Journal of Chemical Education, 81(4), 558.

Matthews, M., \& James T. (1997). "Robinsons account of the philosophy of science and science teaching: Some lessons for today from the 1960s." Science Education, 81(3), 295-315.

Matthews, M. R. (2012). Changing the focus: From nature of science to features of science. In M. S. Khine (Ed.), Advances in nature of science research (pp. 3-26). Dordrecht: Springer.

Matthews, M. R. (2015). Science teaching: The contribution of history and philosophy of science. New York: Routledge.

McComas, W. (Ed.). (1998). The nature of science in science education. Rationales and strategies.

Milanovic, V. D., \& Trivic, D. D. (2017). The historical or the contemporary context: Which of the two ensures a deeper understanding of gas properties? Chemistry Education Research and Practice, 18(4), 549-558.

National Research Council. (1996). National science education standards. Washington: National Academy Press.

National Research Council. (2011). A framework for K-12 science education: Practices, crosscutting concepts, and core ideas. Washington, DC: National Academies Press.

Niaz, M., \& Rodriguez, M. A. (2002). Improving learning by discussing controversies in the 2oth century physics. Physics Education, 37(1), 5963.

Nussbaum, J. (1985a). The particulate nature of matter in the gaseous phase. In R. driver, E. guesen and A. Tibergien (Eds.), Children's ideas in science (pp. 124-144). MiltonKeynes: Open University Press.

Nussbaum, J. (1985b). Children's conception of the earth as a cosmic body: A cross-age study. In R. driver, E. guesen and A. Tibergien (Eds.), Children's ideas in science (pp. 170-192). Milto nKeynes: Open University Press.

Owen, R., Macnaghten, P., \& Stilgoe, J. (2012). Responsible research and innovation: From science in society to science for society, with society. Science and Public Policy, 39(6), 751-760.

Parchmann, I., \& Komorek, M. (2008). The model of educational reconstruction-A research model for the investigation of students' and teachers' conceptual ideas. In R. B., \& I. Eilks (Eds.), Promoting successful science education - the worth of science education research (pp. 169181). Aachen, Germany: Shaker Verlag.

Planinšič, G., \& Kovač, P. (2008). Nano goes to school: A teaching model of the atomic force microscope. Physics Education, 43, 37-45.

Putnam, R. T., \& Borko, H. (2000). What do new views of knowledge and thinking have to say about research on teacher learning? Educational Researcher, 29, 4-15.

Sakhnini, S., \& Blonder, R. (2015). Essential concepts of nanoscale science and technology for high school students based on a Delphi study by the expert community. International Journal of Science Education, 37(11), 1699-1738.

Sakhnini, S., \& Blonder, R. (2016). Nanotechnology applications as a context for teaching the essential concepts of NST. International Journal of Science Education, 38(3), 521-538

Schummer, J. (2007). Identifying ethical issues of nanotechnologies. In H. ten Have (Ed.), Nanotechnologies, ethics and politics (pp. 79-98). Paris: UNESCO.

Schwab, J. (1962). The teaching of science as enquiry. In: J. Schwab \& P. Brandwein (Eds.), The teaching of science (pp. 3-103). Cambridge, MA: Harvard University Press.

Schwartz, R. S., Lederman, N. G., \& Abd-El-Khalick, F. (2012). A series of misrepresentations: A response to Allchin's whole approach to assessing nature of science understandings. Science Education, 96(4), 685-692.

Schwarzer, S., Akaygün, S., Sagun-Coko, B., Anderson, S., \& Blonder, R. (2015). Using Atomic Force Microscopy in out-of-school settings: Two case studies investigating knowledge and understanding of high school students. Journal of Nano Education, 7, 10-27.

Shibley, I. A. (2003). Using newspapers to examine the nature of science. Science \& Education, 12, 691-702.

Shulman, L. S. (1987). Knowledge and teaching: Foundations of the new reform. Harvard Education Review, 57(1), 1-22.

Sjøberg, S., \& Schreiner, C. (2005). How do learners in different cultures relate to science and technology? Results and perspectives from the project ROSE (the Relevance of Science Education). APFSLT: Asia-Pacific Forum on Science Learning and Teaching, 7(1), Foreword.

Srisawasdi, N. (2015). Evaluation of motivational impact of a computer-based nanotechnology inquiry learning module on the gender gap. Journal of Nano Education, 7(1), 28-37.

Stevens, S., Sutherland, L. M., \& Krajcik, J. S. (2009). The big ideas of nanoscale science and engineering: A guidebook for secondary teachers. Arlington, VA: NSTA Press. 
Sutcliffe, H. (2011). A report on responsible research and innovation for the European commission. Retrieved from http://ec.europa.eu/research/science-society/document_library/pdf_o6/rri-report-hilary-sutcliffe_en.pdf.

Sweeney, A. E. (2006). Social and ethical dimensions of nanoscale science and engineering research. Science and Engineering Ethics, $12,435-$ 464.

Tomasik, J. H., Jin, S., Hamers, R. J., \& Moore, J. W. (2009). Design and initial evaluation of an online nanoscience course for teachers. Journal of Nano Education, 1, 48-67.

Toulmin, S., \& Goodfield, J. (1962). The architechture of matter. Princeton: Princeton University Press.

Wanson, S., Mason, T. O., Hershman, M. C., Drane, D., Light, G., Cormia, R., ... Bodner, G. (2009). A rubric for post-secondary degree programs in nanoscience and nanotechnology. International Journal of Engineering Education, 25, 615-627.

Yarden, A. (2009). Reading scientific texts: Adapting primary literature for promoting scientific literacy. Research in Science Education, 39, 307311.

Zhang, J., Chen, P., Yuan, B., Ji, W., Cheng, Z., \& Qiu, X. (2013). Real-space identification of intermolecular bonding with atomic force microscopy. Science, 342(6158), 611-614.

\section{Bionotes}

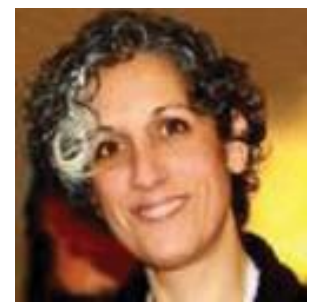

Ron Blonder is a professor of science education and the head of the chemistry group in the Department of Science Teaching, Weizmann Institute of Science. The goal of Prof. Blonder's research group is to bring the chemistry of tomorrow into the high school chemistry lessons of today. Her research addresses three issues: nano-scale science and technology education; science teachers' self-efficacy; and, chemistry teachers' professional development. Her efforts to enhance chemistry teachers' professional development has reached a large number of chemistry teachers via the National Chemistry Teachers' Center, the Rothschild-Weizmann program, the Israeli Chemical Society, and EU-projects. She led the Weizmann Institute's team in the Irresistible project, FP-7 EU-project dealt with responsible research and innovation (RRI) for high school science. Professional site: http://www.weizmann.ac.il/st/blonder/

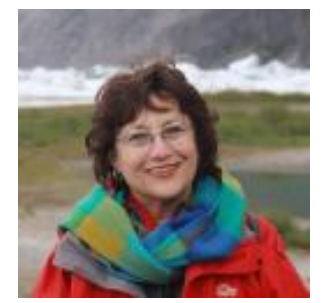

Dr. Rachel Mamlok-Naaman studied chemistry and chemistry education. She is the head of the National Center for Chemistry Teachers at the Department of Science Teaching of the Weizmann Institute of Science. Rachel was also the coordinator of chemistry teachers' programs in the framework of the Rothschild-Weizmann MSc program for science teachers, and of projects in the framework of the European Union (the FP7 programs) in Israel: PARSEL, PROFILES,TEMI, and today - an external evaluator of ARTIST, a project in the framework of Erasmus. In addition: (i) an ACS senior member, and representative of the Israel Chemical Society to the various international organizations of chemistry education, including being a titular member of IUPAC CCE and the secretary of EuCheMS DivCED; (ii) the ICS contact person for all matters of chemistry education and relevant activities; and (iii) a member of editorial and advisory boards for journals and organizations of science education. Rachel's main focus and publications are related to students' learning and to teachers' professional development. For her work on chemistry teachers' professional development in Israel, she received the 2016 Maxine Singer Prize for outstanding scientists at the Weizmann Institute. However, her contributions to chemistry education research and her publications are in several areas, which are integrated into each other, and guide her in conducting professional development courses for chemistry teachers, and in supporting individual teachers in their work: (i) development, implementation, and evaluation of new curricular materials, (ii) research on students' perceptions of chemistry concepts (especially bonding and structure), (iii) inquiry-type skills and activities, including teaching and learning indifferent cultures (e.g., argumentation, asking questions, hypothesizing), (iv) relevance in chemistry education, (v) the nature of science, and (vi) education for sustainable development (ESD), for which she has been selected as a 2018 Awardee for the ACS-CEI Award for Incorporation of Sustainability into the Chemistry Curriculum. 